\section{MIIIESE}

"la Caixa" Chair of Corporate Social

Responsibility and Corporate Governance
Working Paper

WP no 701

July, 2007

University of Navarra

\title{
RESPONSIBLE CORPORATE GOVERNANCE: TOWARDS A STAKEHOLDER BOARD OF DIRECTORS?
}

\author{
Silvia Ayuso \\ Antonio Argandoña
}




\title{
RESPONSIBLE CORPORATE GOVERNANCE: TOWARDS A STAKEHOLDER BOARD OF DIRECTORS?
}

\author{
Silvia Ayuso* \\ Antonio Argandoña**
}

\section{Abstract}

The central question posed in this paper will be how to organize board composition in order to ensure a responsible corporate governance both from a CSR and a good governance perspective. Adopting a stakeholder approach to corporate governance, we analyze the arguments given by different theoretical approaches for linking specific board composition with financial performance and CSR, and discuss the empirical research conducted. Despite the inconclusive findings of empirical research, it can be argued that diverse stakeholders on the board will promote CSR activities within the firm, but at the same time will increase board capital (which ultimately may lead to a better financial performance). Finally, we propose a model for selecting board members based both on ethical and pragmatic arguments.

* Postdoctoral Research Fellow, IESE

** Professor of Economics, "la Caixa" Chair of Corporate Social Responsibility and Corporate Governance

Keywords: board composition, corporate governance, corporate social responsibility, financial performance, stakeholders. 


\section{RESPONSIBLE CORPORATE GOVERNANCE: TOWARDS A STAKEHOLDER BOARD OF DIRECTORS?*}

\section{Introduction}

As corporate social responsibility (CSR) has become an increasingly prominent issue for companies, corporate boards of directors are becoming more involved in assessing and shaping company policies and practices on a wide range of social and environmental topics. At the same time that companies' overall CSR performance has come under the spotlight, a parallel "good governance" movement has put the structure, composition and behavior of corporate boards under scrutiny. Shareholder activists and other stakeholders are demanding that corporate directors be more active and independent of management, and that corporate boards more accurately reflect a broad range of constituents. But, how does good corporate governance relate to CSR? The present paper attempts to address this question.

Although "corporate governance" has received a great deal of media attention lately, the term is still relatively new. Usually, corporate governance refers to the system by which organizations are directed and controlled and which specifies the distribution of rights and responsibilities among shareholders and managers and the rules and procedures for making decisions on corporate affairs. However, in a wider sense, corporate governance also includes the relationships with a broader range of firm stakeholders, both internal (employees) and external (customers, suppliers, etc.). In this regard, Tirole $(2001$, p. 4) proposes a definition of corporate governance as "the design of institutions that induce or force management to internalize the welfare of stakeholders".

According to an early analysis by Berle and Means (1932), the problem of corporate governance arises from the separation of ownership and control in public corporations and aims at solving the problems of possible opportunistic behavior by managers (agents) towards shareholders (principals). But corporate governance also has to face the problem of the distribution of the quasi-rents produced by the firm, which again leads to a conflict between principals and agents

\footnotetext{
* This paper is part of the research activities of the "la Caixa" Chair of Corporate Social Responsibility and Corporate Governance at IESE Business School.

This paper was presented at the Fifth National Conference of Ethics of Economics and Organizations (XV Congreso Nacional de Etica de la Economía y de las Organizaciones), Barcelona, 8-9 June 2007.
} 
- and other multiple stakeholders contributing to the generation of quasi-rents: employees, customers, suppliers, local community, environment and society in general. This connects with the question of whose interest the corporation should serve and who should be the beneficiaries of firm-created value. Broadly speaking, we can differentiate between a shareholder perspective and a stakeholder perspective of the firm (Letza et al., 2004; Szwajkowski, 2000; Vinten, 2001). The shareholding model regards the corporation as a legal instrument for shareholders to maximize their own interests, i.e. investment returns. More in line with the CSR strategy is the stakeholding approach that views the corporation as a locus of responsibility in relation to a wide array of stakeholders' interests or, in words of Tirole $(2001$, p. 24), as "maximizing the sum of the various stakeholders' surpluses".

This stakeholder approach to corporate governance implies a shift in the traditional role of the board of directors as defenders of shareholders' interests. As the highest governance body, directors are responsible for setting the values and standards within the organization through their decisions regarding strategy, incentives and internal control systems. Thus, a board that commits to CSR and seeks to address the needs of diverse stakeholders may have to adapt its composition and functioning to this new role. However, as noted by Ricart et al. (2005), little attention has been paid so far to the implications of CSR for corporate governance. Academic research has focused until now on two aspects of socially responsible firms: CEO compensation (e.g. Frye et al., 2006; Mahoney and Thorn, 2006; McGuire et al., 2003) and board structure (Ayuso et al., 2007; Hillman, Keim and Luce, 2001; Webb, 2004). In this paper, we will only look at board composition as a governance mechanism for taking into account the stakeholder concerns.

The central question posed in this paper will be how to organize board composition in order to ensure responsible corporate governance both from a CSR and a good governance perspective. This question will be approached in the following way. First, we review the stakeholder approach to corporate governance as an alternative to the shareholder-focused conception of the firm. Second, we focus on the composition of the board of directors, and examine the recommendations made by corporate governance guidelines and codes of best practices. We analyze the arguments given by different theoretical approaches for linking specific board composition with financial performance and CSR, and discuss the empirical research conducted. Finally, we propose a model for selecting board members based both on ethical and pragmatic arguments.

\section{The Stakeholder Approach to Corporate Governance}

According to stakeholder theory, companies should design their corporate strategies considering the interests of their stakeholders - groups and individuals who can affect or are affected by the organization's purpose (Freeman, 1984). In this sense, stakeholders of a firm can be defined as "individuals and constituencies that contribute, either voluntarily or involuntarily, to its wealth-creating capacity and activities, and who are therefore its potential beneficiaries and/or risk bearers" (Post et al., 2002, p. 8). The company can pay attention to these groups for at least two reasons (Donaldson and Preston, 1995). First, it can be considered that their demands have intrinsic value (normative approach), so that the company has the responsibility to meet their legitimate claims. Second, addressing the interests of stakeholders who are perceived to have influence can improve company profitability (instrumental approach). Stakeholder theory is related to the literature of corporate sustainability and CSR, since it provides a convincing theoretical framework for analyzing the relationship between company and society (Clarkson, 
1995; Harrison and Freeman, 1999; Mintzberg, 1983). Some authors, like Freeman and Velamuri (2006), even affirm that the main objective of CSR is to create value for stakeholders and to fulfill responsibilities towards them.

With regard to corporate governance, stakeholder theory has led to an alternative approach to the conventional shareholder-wealth-maximizing firm. Compared to the singular goal of raising shareholder returns, the stakeholder firm has multiple objectives related with its diverse stakeholders. The shareholder-maximizing model is premised on the notion that owners risk their investment capital and are the sole residual claimants, while other parties (e.g., employees) are compensated on the basis of their marginal products (i.e., paid wages set by competitive labor markets). The governance process, therefore, is controlling managers and other organizational participants to ensure that they act in the owners' interests. In contrast, one can argue that multiple firm stakeholders risk their 'investments' to achieve their goals, and thus each of them has a legitimate or moral right to claim a share of the value created or the firm's residual resources (Blair, 1995). Under this view, the governance structure shifts from a principal-agent to a team production problem, and the critical governance tasks become to ensure effective negotiations, coordination, cooperation and conflict resolution to maximize and distribute the joint gains among multiple parties of interest. For a stakeholder firm to be viable over time, it must demonstrate its ability both to achieve the multiple objectives of the different parties and to distribute the value created in ways that maintain their commitment. The key distinguishing features of the shareholder and stakeholder perspectives are summarized in Table 1.

\section{Table 1}

Key Distinctions Between the Shareholder and Stakeholder Perspective of Corporate Governance (Adapted from Kochan and Rubinstein, 2000)

\begin{tabular}{|l|l|l|}
\hline & Shareholder perspective & Stakeholder perspective \\
\hline Purpose & Maximize shareholder wealth & $\begin{array}{l}\text { Pursue multiple objectives of parties with } \\
\text { different interests }\end{array}$ \\
\hline $\begin{array}{l}\text { Governance } \\
\text { structure }\end{array}$ & $\begin{array}{l}\text { Principal-agent model (managers are } \\
\text { agents of shareholders) }\end{array}$ & Team production model \\
\hline $\begin{array}{l}\text { Governance } \\
\text { process }\end{array}$ & Control & $\begin{array}{l}\text { Coordination, cooperation and conflict } \\
\text { resolution }\end{array}$ \\
\hline $\begin{array}{l}\text { Performance } \\
\text { metrics }\end{array}$ & $\begin{array}{l}\text { Shareholder value sufficient to } \\
\text { maintain investor commitment }\end{array}$ & $\begin{array}{l}\text { Fair distribution of value created to maintain } \\
\text { commitment of multiple stakeholders }\end{array}$ \\
\hline $\begin{array}{l}\text { Residual risk } \\
\text { holder }\end{array}$ & Shareholders & All stakeholders \\
\hline
\end{tabular}

According to the normative stream of stakeholder theory, the consideration of the company's different stakeholder groups can be seen as an ethical demand. Consequently, some authors propose the representation of diverse stakeholders on corporations' boards in order to legitimize (Evan and Freeman, 1993) and safeguard the interests of corporate stakeholders (Freeman and Evan, 1990) and to ensure that their concerns are considered in corporate decision-making 
(Jones and Goldberg, 1982). According to Luoma and Goodstein (1999), three dimensions of board structure and composition are particularly important in reflecting the degree to which concern about stakeholders has been integrated into corporate decision-making: the presence of stakeholders as directors, their appointment in monitoring or oversight board committees (audit, compensation, executive or nominating), and the existence of a committee composed mainly of stakeholders or dedicated to CSR.

Within the instrumental approach of the stakeholder model, several economic arguments have been proposed to justify this vision of the firm (Rodriguez, 2003). One of the main arguments is the recognition of the firm-specific investments made by stakeholders. Rajan and Zingales (1998) and Zingales (1998) argue that the company has to safeguard the interests of all who contribute to the general value creation, that is, make specific investments to a given corporation. These firm-specific investments can be diverse and include physical, human and social capital. These specific investments are of little or no value outside of the firm and cannot be protected by full contracts ex ante, nor evaluated independently from the firm's functioning.

The problem with these firm-specific investments is, as we have said before, that they produce quasi-rents that can be expropriated by some of the firm constituencies (included the external stakeholders). Thus, they can cause a potential conflict among stakeholders that may shrink the cooperation and, therefore, the creation of value. Blair and Stout (1999) claim that it is the board that has to take on the task of governing the firm-specific investments and mediating between investors' possible conflicting interests in firm-specific assets. Recently, Kaufman and Englander (2005) used the team production model to recommend that company board members should represent all those stakeholders that add value, assume unique risks and possess strategic information for the corporation. Shareholders still have to be present in corporate boards, because they "create and destroy" a firm's value via its market price and because the board remains accountable to shareholders through financial markets and governance law. But employees (both managers and workers) may add value by firm-specific human capital investments, hold tacit knowledge relevant to the firm and thus incur in unique risks much like proprietary shareholders. Consequently, these employees should be included in the board, along with other outside stakeholders who can provide strategic information about new product market opportunities and current technological research. Even if Kaufman and Englander's proposal focuses on sustaining the firm's core capabilities and does not consider responsibility issues, their arguments do connect with CSR. ${ }^{1}$ In sum, the board must have directors who can knowledgeably express the multiple constituents' interests both for ethical and economic reasons. But the question remains: How should the board choose members to represent, either directly or indirectly, the different stakeholder groups?

\section{Board Composition and its Effect on Financial Performance and CSR}

Board composition is a central issue in the multiplicity of corporate governance guidelines and codes of best practices that have been published at the international and national level (e.g. OECD Principles of Corporate Governance, ICGN Statement, World Bank Framework for

\footnotetext{
${ }^{1}$ Although Kaufman and Englander (2005) acknowledge that third-party non-contractual stakeholders, such as the community or the environment, may also incur in non-diversifiable risks and that their interest should be addressed at the board level, the authors do not elaborate on this issue further.
} 
Implementation). Most of these guidelines are directed at increasing board accountability to shareholders and improving board effectiveness. There have also emerged voluntary codes of conduct that include governance as part of a larger corporate social responsibility agenda, e.g., standards within the Global Reporting Initiative and the UN Global Compact. Usually, these governance recommendations call for more board independence, and in some instances also for increased board diversity and better response to stakeholders.

Board composition has also been a focus of much of the academic research on corporate governance, particularly with regard to its effects on corporate performance. Compared to the extant research on the board-financial performance relationship, much less attention has been paid to the question of how specific board attributes influence CSR. Next, we review the arguments put forward by different theoretical approaches (mainly agency theory and resource dependency theory) for linking specific board composition with financial performance and CSR, and examine the empirical research conducted so far.

\section{Independent Directors}

A common recommendation in corporate governance codes is to increase the proportion of independent directors on the board. The vast majority of governance research has argued for this prescription from an agency theory perspective. Agency theorists see the primary function of boards of directors as monitoring the actions of managers on behalf of shareholders (Eisenhardt, 1989; Jensen and Meckling, 1976). Board independence - the degree to which board members are dependent on the current CEO or organization - is considered key to the effectiveness of board monitoring (Fama and Jensen, 1983; Jensen and Meckling, 1976). Boards consisting primarily of insiders (current or former managers/employees of the firm) or dependent outside directors (directors who have business relationships with the firm and/or family or social ties with the (EO) are considered to be less effective in monitoring because of their dependence on the organization. Independent boards - those primarily consisting of independent outside directors - are thought to be the most effective at monitoring because their incentives are not compromised by dependence on the CEO or the organization. Although some empirical support has been found for this hypothesis linking independent boards with firm performance, other research does not support this position (see Table 2).

An alternative perspective would suggest that inside directors have more and better information which allows them to evaluate managers more effectively (Baysinger and Hoskisson, 1990). This approach fits with resource dependence theory. Resource dependence theorists view a firm as an open system, dependent on external organizations and environmental contingencies (Pfeffer and Salancik, 1978). Proponents of this perspective see corporate boards as resource providers. Four types of resources are provided by boards: 1) advice and counsel, 2) legitimacy, 3) channels for communicating information between the firm and external organizations, and 4) preferential access to commitments or support from important elements outside the firm (Hillman et al., 2000; Pfeffer and Salancik, 1978). By linking the firm with its external environment, resources help reduce external dependency (Pfeffer and Salancik, 1978), diminish environmental uncertainty (Pfeffer, 1972) and lower transaction costs (Williamson, 1984), and ultimately improve firm performance. Both inside and outside directors may bring important linkages and resources to the board, but directors who have ties to the current CEO/organization will be more motivated to 
provide resources (Hillman and Dalziel, 2003). ${ }^{2}$ Despite the empirical support for this assertion (e.g. Kesner, 1987; Westphal, 1999), a recent meta-analysis of fifty-four studies showed no statistically significant relationship between board dependence and the firm's financial performance (Dalton et al., 1998).

With regard to CSR, most recommendations favor the role of independent directors. Resource dependence theory suggests that the selection of outside members will provide more resources, information, and legitimacy to the board. Hence, outside board members will be more likely than inside directors to oppose a narrow definition of organizational performance which focuses primarily on financial measures and will tend to be more sensitive to society's needs (Ibrahim and Angelidis, 1994; Ibrahim et al., 2003). In addition, outside directors may be more knowledgeable about the changing demands of various stakeholders and may feel freer to advocate costly or unpopular decisions, such as those that involve compliance issues (Johnson and Greening, 1999; Zahra et al., 1993). Although some empirical support has been found for a better CSR performance of firms with independent boards, several studies found no relationship between board independence and CSR (see Table 2).

\section{Table 2}

Empirical Studies on the Effects of Independent Directors on Financial Performance and Corporate Social Responsibility (CSR)

\begin{tabular}{|c|c|c|}
\hline & Positive findings & Neutral or negative findings \\
\hline $\begin{array}{l}\text { Financial } \\
\text { performance }\end{array}$ & $\begin{array}{l}\text { Baysinger and Butler (1985): Firms } \\
\text { with more outside board members } \\
\text { performed better than those with a } \\
\text { majority of insiders on the board. } \\
\text { - Ezzamel and Watson (1993): } \\
\text { Outside directors are positively } \\
\text { associated with firm profitability. } \\
\text { - } \\
\text { Rosenstein and Wyatt (1990): An } \\
\text { increase in stock price was } \\
\text { correlated with the addition of } \\
\text { outsiders to the board of directors. }\end{array}$ & $\begin{array}{l}\text { - Agrawal and Knoeber (1996): More } \\
\text { outsiders on the board are negatively } \\
\text { related to performance. } \\
\text { de Andres et al. (2005): There is no } \\
\text { relationship between the proportion of } \\
\text { outsider directors and firm value. } \\
\text { Dulewicz, and Herbert (2004): There is } \\
\text { no relationship between the proportion } \\
\text { of outside or executive directors on the } \\
\text { board and company performance. }\end{array}$ \\
\hline CSR & $\begin{array}{l}\text { - Ibrahim and Angelidis (1995), Ibrahim } \\
\text { et al. (2003): Outside directors exhibit } \\
\text { greater concern about the } \\
\text { philanthropic component of corporate } \\
\text { responsibility than inside directors. } \\
\text { Johnson and Greening (1999): } \\
\text { Outside director representation is } \\
\text { positively related to corporate social } \\
\text { performance. } \\
\text { Webb (2004): Socially responsible } \\
\text { firms tend to have boards with more } \\
\text { outsiders. } \\
\text { Zahra et al. (1993): The percentage } \\
\text { of outside directors is positively } \\
\text { associated with corporate social } \\
\text { responsibility. }\end{array}$ & $\begin{array}{l}\text { - Chapple and Ucbasaran (2007): The } \\
\text { ratio of outsiders/insiders on the board } \\
\text { is not related to CSR activity. } \\
\text { - McKendall et al. (1999): The proportion } \\
\text { of inside directors to outside directors is } \\
\text { not related to environmental law } \\
\text { violations. } \\
\text { - Wang and Dewhirst (1992): Inside and } \\
\text { outside directors do not differ in their } \\
\text { stakeholder orientation. }\end{array}$ \\
\hline
\end{tabular}

\footnotetext{
2 In line with Hillman and Dalziel (2003), we refer to resource dependence theory in the sense of dependence of the firm on both external and internal resources. This interpretation is more in line with the resource-based theory of the firm.
} 
Although similar in its discussion of the relationship between board composition and financial performance, agency theory suggests the opposite argument. Since CSR offers no obvious direct financial benefit to shareholders, agents are more likely than principals to invest in CSR because they have no direct residual claims on a firm's income (Wang and Coffey, 1992). Furthermore, agents may be driven by self-interests to pursue CSR activities, such as membership of a social elite, immortality and distracting from mismanagement (Coffey and Wang, 1998). Thus, following agency theory logic, inside or dependent directors will have a stronger interest in CSR than independent directors. In contrast, boards dominated by independent directors will be more effective in monitoring and limiting managerial opportunism linked to CSR.

\section{Female and Minority Directors}

Numerous governance guidelines advocate increased representation by women and minorities on corporate boards of directors to better reflect the gender and racial diversity of their customers, employees, and other stakeholders. The request for greater boardroom diversity is based primarily on normative grounds of equity and fairness (Carter et al., 2007). Corporations, organizations and individuals seldom publicly dispute the proposition that women and ethnic minorities deserve equitable opportunities to serve on the board and in upper management positions. But at the same time, several arguments are made for the business case for board diversity. Agency theory suggests that a more diverse board is a better monitor of managers because board diversity increases board independence (Carter et al., 2007). According to this view, diverse directors are less likely to collude with other directors to subvert shareholders than more homogeneous boards are. Furthermore, board diversity can increase board independence because people with different gender, ethnicity or cultural background might ask questions that would not be asked by directors with more traditional backgrounds. Other propositions for promoting board diversity can be supported by resource dependence theory, since a more diverse board appears to increase the resources brought in by individual board members and the organization's access to external resources. Hence, board diversity has been advocated as a mean of providing new insights and perspectives, increasing creativity and innovation, enhancing board decision-making and promoting more effective global relationships (Carter et al., 2003; van der Walt and Ingley, 2003). Consequently, most researchers assume a positive relationship between board diversity and organizational performance. However, empirical studies analyzing the effects of the gender and ethnicity characteristics of board members have produced mixed results (see Table 3). Whereas Carter et al. (2003) and Erhardt et al. (2003) found significant positive relationships between the presence of women and ethnic minorities (i.e. African, Hispanic, Asian and Native Americans) on corporate boards and their impact on firm performance or shareholder wealth, other studies found negative or no statistically significant relationships between board diversity and financial performance.

Female and minority directors are also usually assumed to play an important role in favoring CSR strategies. Since resource dependence theory suggests that board members bring resources to the organization as a result of their individual background, an increased representation of women and ethnic minorities will increase board attention to CSR issues of racial and gender imbalances. Some studies also affirm that female directors tend to be more sensitive to CSR than their male counterparts (e.g. Ibrahim and Angelidis, 1994). In any case, as members of underrepresented groups in corporations, women and minority directors are expected to be 
more interested in the welfare of various stakeholders. As shown in Table 3, several studies support this view.

\section{Table 3}

Empirical Studies on the Effects of Independent Directors on Financial Performance and Corporate Social Responsibility (CSR)

\begin{tabular}{|c|c|c|}
\hline & Positive findings & Neutral or negative findings \\
\hline $\begin{array}{l}\text { Financial } \\
\text { performance }\end{array}$ & $\begin{array}{l}\text { - Carter et al. (2003): Presence of } \\
\text { women or minorities on corporate } \\
\text { boards positively affects firm value. } \\
\text { - } \quad \text { Erhardt et al. (2003): Ethnic and } \\
\text { gender representation on boards } \\
\text { increases firm financial performance. }\end{array}$ & $\begin{array}{l}\text { - Shrader et al. (1997): Presence of } \\
\text { women on the board is negatively } \\
\text { related to firm financial performance. } \\
\text { Zahra and Stanton (1988): Female and } \\
\text { ethnic minority representation on } \\
\text { boards is not associated with firm } \\
\text { financial performance. }\end{array}$ \\
\hline CSR & $\begin{array}{l}\text { - Coffey and Wang (1998), Wang and } \\
\text { Coffey (1992): Proportion of women } \\
\text { (and minority directors) is positively } \\
\text { related to corporate philanthropy. } \\
\text { - Webb (2004): Socially responsible } \\
\text { firms have more women on the } \\
\text { board. } \\
\text { - Williams (2003): Firms with a higher } \\
\text { proportion of women on their boards } \\
\text { engage to a greater extent in } \\
\text { charitable giving. } \\
\text { Siciliano (1996): Firms with more } \\
\text { women on the board have higher } \\
\text { levels of social performance. }\end{array}$ & $\begin{array}{l}\text { - Stanwick and Stanwick (1998): The } \\
\text { percentage of women and minorities on } \\
\text { the board of directors is not linked to the } \\
\text { firm's corporate social performance. }\end{array}$ \\
\hline
\end{tabular}

\section{Stakeholder Directors}

Although codes of corporate governance increasingly refer to stakeholders' interests, they seldom propose including representatives of non-shareholder stakeholders in the board. So far, not much attention has been paid either to stakeholder directors in corporate governance research. The dominant theoretical perspective, agency theory, does not offer any arguments for adding stakeholder directors to the board. As Kassinis and Vafeas (2002) point out, environmental (and CSR) policies give rise to a different set of conflicts from the "agency conflict": management and shareholder interests are relatively aligned and focused on maximizing profits, and opposed to the interests of the community at large (or other stakeholders). Following their argumentation, it is not important to discern and separate directors who are likely to protect shareholders over management, but instead to discern those directors who are likely to protect the community over management and shareholders. Nonetheless, as in the case of female and minority directors, it can also be argued that a more plural board is a more independent board.

Resource dependency theory provides better arguments for including stakeholder directors on the boards. Since this theoretical perspective underlines the role of directors as resource providers, the traditionally used distinction of inside and outside directors does not adequately capture this role (Hillman et al., 2000). Inside directors are individuals who are current or former managers of the firm. Typical outside directors are active or retired executives in other 
for-profit organizations or directors who serve on other corporate boards. Due to their business experience, they bring a working knowledge of strategic decision-making and internal firm operations. Furthermore, their experience outside the firm enables them to offer alternative viewpoints, providing executives with information about how other firms deal with similar problems and concerns.

However, according to resource dependence logic, a board of directors needs more resources than the expertise, skills, information and potential linkages provided by business experts (Hillman et al., 2000). Different stakeholder directors can provide valuable resources because of their business relationships with the firm (for instance, customers, suppliers and creditors) or non-business connections (government officials, academics and community representatives) (Luoma and Goodstein, 1999). Even though these arguments seem convincing, there has been very little research examining the performance effects of specific stakeholder directors (an exception is Hillman, 2005). A particular case are employee representatives on the board. ${ }^{3}$ Originally justified as a form of industrial democracy or democracy at the company level, today workers participation is mainly emphasized as a contribution to value creating and necessary organizational change (Hagen and Huse, 2006). While some authors argue that board employee representation is dependent on executive managers and contributes to managerial entrenchment (e.g. Hollandts, 2007), others highlight that employees, as internal stakeholders, can provide exclusive company information that may improve board efficiency (e.g. Hagen and Huse, 2006). Empirical research on employee representation on the board and its effect on company performance has shown mixed and partly contradictory results (see Table 4).

Although directors with a business background can leverage their experience on CSR adoption from other boards (Kakabadse et al., 2006; Kassinis and Vafeas, 2002; Webb, 2004), the inclusion of stakeholder directors will presumably lead to more explicit recognition of stakeholder issues and thus CSR. In addition to the arguments of resource dependence theory, some authors refer to stakeholder theory in their call for board directors as representatives and protectors of a broad range of stakeholders (Hillman et al., 2001; Wang and Dewhirst, 1992). Kassinis and Vafeas (2002) suggest that stakeholder directors, such as academics, members of the military and clergy, and politicians have interests that are more closely aligned with the interests of the community at large. Thus, the role of stakeholders' representatives is to enhance not only corporate financial performance, but also, more important, corporate social performance. As shown in Table 4, the few empirical studies that have been conducted so far deliver mixed results for this assertion.

\footnotetext{
${ }^{3}$ Many European countries have laws concerning mandatory codetermination that allow employees to select up to one third of the (supervisory) board members (Osterloh et al., 2007).
} 


\section{Table 4}

Empirical Studies on the Effects of Stakeholder Directors on Financial Performance and Corporate Social Responsibility (CSR)

\begin{tabular}{|c|c|c|}
\hline & Positive findings & Neutral or negative findings \\
\hline $\begin{array}{l}\text { Financial } \\
\text { performance }\end{array}$ & $\begin{array}{l}\text { - FitzRoy and Kraft (2005): Introduction of } \\
\text { parity codetermination has a slight } \\
\text { positive effect on productivity. } \\
\text { - Hillman (2005): Firms with ex-politicians } \\
\text { on the board are associated with better } \\
\text { market performance, especially within } \\
\text { heavily regulated industries. }\end{array}$ & $\begin{array}{l}\text { - FitzRoy and Kraft (1993): Board } \\
\text { codetermination has a negative effect on } \\
\text { productivity and no significant effect on } \\
\text { profits. }\end{array}$ \\
\hline CSR & $\begin{array}{l}\text { - Kassinis and Vafeas (2002): The } \\
\text { presence of stakeholder directors } \\
\text { decreases the likelihood of firms violating } \\
\text { environmental laws. } \\
\text { - Siciliano (1996): Firms with boards } \\
\text { representing diverse occupational } \\
\text { backgrounds have higher levels of social } \\
\text { performance. }\end{array}$ & $\begin{array}{l}\text { - Hillman et al. (2001): The presence of } \\
\text { stakeholder directors is not related to } \\
\text { stakeholder performance. } \\
\text { Webb (2004): Socially responsible firms are } \\
\text { not likely to have more board members } \\
\text { involved with non-profit organizations. }\end{array}$ \\
\hline
\end{tabular}

\section{Towards a Stakeholder Board}

Empirical findings on the effects of board composition support different corporate governance theories. The coexistence of different theoretical approaches can be explained by the fact that each perspective emphasizes a different role of the board of directors. Whereas agency theory focuses on the monitoring or control function of the board, resource dependency theory stresses the role of the board as a provider of resources (Hillman and Dalziel, 2003). There is general consensus in the corporate governance literature that outside directors, especially those without any other affiliation with the firm, will be more effective in evaluating management based on their increased objectivity (Dalton et al., 1998). From the literature reviewed, it becomes evident that directors from a variety of constituencies and with a variety of expertise will be more effective in performing the resource provision function. ${ }^{4}$

Stakeholder theory introduces a new role of the board: balancing stakeholder interests (Kakabadse and Kakabadse, 2007). As referred earlier, stakeholder theory has both normative (moral/ethical) and instrumental (profit/wealth-enhancing) implications. From the normative viewpoint, we can argue that if the function of the board is to protect the interests of the corporation's stakeholders, the board should comprise members that are representative of these stakeholders. Including stakeholders on corporate boards can be a formal mechanism that acknowledges the importance of their relationship with the firm (Mitchell and Agle, 1997) and ensures that the interests and well-being of constituents other than shareholders are given legitimate consideration in board decision-making (Luoma and Goodstein, 1999). Furthermore, the institutionalization of stakeholders inclusion on the board will become an important element of the firm's CSR strategy, by formally introducing non-economic considerations into corporate decision-making.

Stakeholder directors are likely to be knowledgeable about the interests of the groups from which they are drawn and to bring a broader perspective on the interests of stakeholders in general (Hillman et al., 2001). At the same time, firms with stakeholders on their boards are

\footnotetext{
${ }^{4}$ Hillman and Dalziel (2003) argue that other board roles considered in the corporate governance literature like "strategy" and "service", can be understood as part of the provision of resources function.
} 
signaling their commitment to stakeholders in a visible way. This may in turn provide increased legitimacy for the firm and increase a firm's linkages to important external and internal contingencies. Hence, from the instrumental viewpoint, including stakeholders on corporate boards increases what Hillman and Dalziel (2003) call board capital. This capital consists of both human capital (expertise, experience, knowledge, reputation and skills) and relational capital (ties to strategically relevant organizations). Ultimately, the presence of various stakeholder directors will secure an increased provision of relevant resources by the board and facilitate the firm's interactions with its multiple stakeholder groups.

In our view, stakeholder theory suggests incorporating various firm's stakeholders on the board, both to give them a legitimate voice and to respond better to the resource dependencies the firm faces. In order to differentiate among stakeholder types, we adopt the classification made by Rodriguez et al. (2002): consubstantial, contractual and contextual stakeholders (see Figure 1). Consubstantial stakeholders are the stakeholders that are essential for the business's existence (shareholders and investors, strategic partners, employees). Contractual stakeholders, as their name indicates, have some kind of formal contract with the business (financial institutions, suppliers and sub-contractors, customers). Contextual stakeholders are representatives of the social and natural systems in which the business operates and play a fundamental role in obtaining business credibility and, ultimately, the acceptance of their activities (public administration, local communities, countries and societies, knowledge and opinion makers).

\section{Figure 1}

Stakeholders of the Firm (Adapted from Rodriguez et al., 2002)

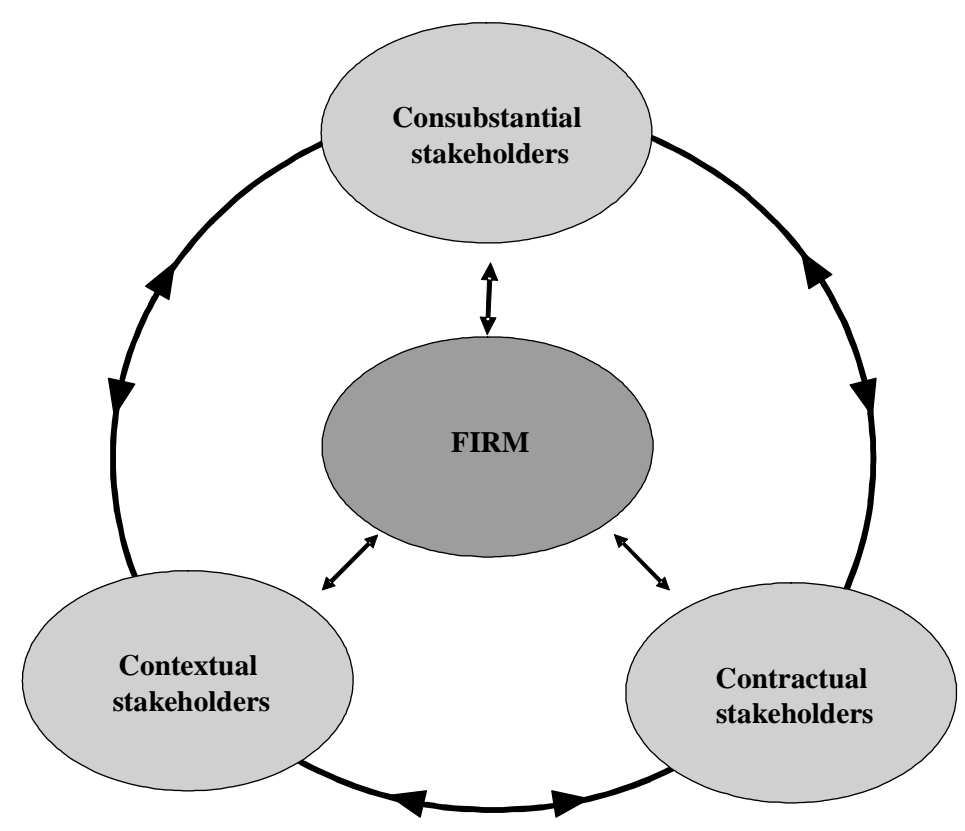

Firms must assess the stakeholders that are relevant to them because of their specific business and environment and select board members who represent them adequately, also bearing in mind diversity issues such as giving equal opportunities to women and ethnic minorities. These stakeholders, in turn, will be able to provide the needed board capital, i.e. human and relational capital, to allow the firm to create value. Table 5 shows the different types of stakeholder directors and outlines the kinds of resources and linkages which the director is expected to bring to the board. 


\section{Table 5}

Board Capital of Stakeholder Directors

\begin{tabular}{|l|l|}
\hline Director category & Resources provided \\
\hline $\begin{array}{l}\text { Representative of consubstantial } \\
\text { stakeholders }\end{array}$ & $\begin{array}{l}\text { Expertise on the firm itself. } \\
\text { Firm-specific knowledge in areas such as finance, law, technology, } \\
\text { science, etc. }\end{array}$ \\
\hline $\begin{array}{l}\text { Representative of contractual } \\
\text { stakeholders }\end{array}$ & $\begin{array}{l}\text { Specialized expertise on law, banking, insurance, etc. } \\
\text { Channels of communication to product or supply market. } \\
\text { Access to resources, such as financial capital and legal support. }\end{array}$ \\
\hline $\begin{array}{l}\text { Representative of contextual } \\
\text { stakeholders }\end{array}$ & $\begin{array}{l}\text { Non-business perspectives on issues, problems and ideas. } \\
\text { Channels of communication to community. }\end{array}$ \\
\hline
\end{tabular}

\footnotetext{
${ }^{1}$ We refer to representatives of non-shareholder stakeholders since representation of shareholders' interests has been extensively treated in corporate governance literature.
}

Our proposal for stakeholder directors is similar to Hillman et al. (2000) taxonomy of the resource dependence role of directors. But while Hillman and colleagues focus on a firm's need for resources from the external environment, we also consider internal resources. In this sense, our proposal for a stakeholder board is more in line with Kaufman and Englander (2005) board selection criteria based on a team production model: the board should represent stakeholders that add value, assume unique risks and possess strategic information. However, we emphasize that consubstantial, contractual and contextual stakeholders of the firm contribute to its wealth creation and should be included in the governance board, and that the board also has the responsibility to reflect societal diversity.

\section{Conclusion}

The present paper attempts to explore the question of how to organize board composition in order to ensure responsible corporate governance. Since CSR suggests that companies have responsibilities that go beyond the interests of their shareholders, it advocates a stakeholder approach to corporate governance. In contrast to the conventional shareholder-wealthmaximizing firm, the stakeholder approach to corporate governance views the firm as a socioeconomic organization built to create wealth for its multiple constituencies, and, ultimately, calls for representing the different stakeholders on the board. From an ethical point of view, having stakeholder directors on the board ensures that their rights and legitimate expectations will be respected. From an economic perspective, a board that replicates the firm's internal and external stakeholders fosters their commitment in contributing to value creation and guarantees that their firm-specific investments will not be "expropriated" and their assumed risks will be properly protected. Directors who represent the firm's internal and external stakeholders will also bring strategic information to the board. This argument connects with the managerial perspective and, in particular, resource dependency theory, since directors from a variety of constituencies will be able to provide important resources in order to assist the firm in creating and sustaining competitive advantage. Despite the inconclusive findings of empirical research, 
it can be argued that diverse stakeholders on the board will promote the firm's CSR activities, but, at the same time, will increase board capital (which ultimately may lead to a better financial performance).

The present paper makes several contributions. First, it challenges the often-made assumption that good corporate governance focuses exclusively on shareholders' interests and argues for taking stakeholders' interest into account. Second, it seeks to reconcile different corporate governance theories and connect economic and managerial argumentations. Third, it makes a proposal that is relevant for both researchers and practitioners. For scholars, it shows the relevance of board directors as providers of important resources and adds a new role of the board: balancing stakeholders' interests. For practitioners, it suggests a normative and strategic dimension when selecting directors in order to ensure responsible corporate governance, both from a CSR and a good governance perspective. 


\section{References}

Agrawal, A. and C.R. Knoeber (1996), "Firm Performance and Mechanisms to Control Agency Problems between Managers and Shareholders," Journal of Financial \& Quantitative Analysis, 31, 3, pp. 377-397.

Ayuso, S., M.A. Rodríguez, R. García and M.A. Ariño (2007), "Maximizing stakeholders' interests: An empirical analysis of the stakeholder approach to corporate governance," IESE Working Paper WP No 670.

Baysinger, B.D. and H.N. Butler, (1985), "Corporate Governance and the Board of Directors: Performance Effects of Changes in Board Composition”, Journal of Law, Economics \& Organization, 1, 1, pp. 101-124.

Baysinger, B. and R. Hoskisson (1990), "The Composition of Boards of Directors and Strategic Control: Effects on Corporate Strategy," Academy of Management Review, 15, 1, pp. 72-87.

Berle, A. and G. Means (1932), “The Modern Corporation and Private Property, Macmillan” New York.

Blair, M. (1995), "Ownership and Control: Rethinking Corporate Governance for the TwentyFirst Century”, Brookings, Washington.

Blair, M.M. and L.A. Stout (1999), "A Team Production Theory of Corporate Law," Virginia Law Review, 85, 2, pp. 247-328.

Carter, D.A., B.J. Simkins, and W.G. Simpson, (2003), "Corporate Governance, Board Diversity, and Firm Value," Financial Review 38, 1, pp. 33-53.

Carter, D.A., F. D'Souza, B.J. Simkins, and W.G. Simpson (2007), "The Diversity of Corporate Board Committees and Firm Financial Performance," Available at SSRN: Http://ssrn.com/abstract $=972763$

Chapple, W. and D. Ucbasaran (2007), "The Effects of Corporate Governance on Corporate Social Responsibility”, unpublished.

Clarkson, M.E. (1995), "A Stakeholder Framework for Analyzing and Evaluating Corporate Social Performance," Academy of Management Review, 20, 1, pp. 92-117.

Coffey, B.S. and J. Wang (1998), "Board Diversity and Managerial Control as Predictors of Corporate Social Performance," Journal of Business Ethics, 17, 1, 1595-1603.

Dalton, D.R., C.M. Daily, A.E. Ellstrand, and J.L. Johnson (1998), "Meta-Analytic Reviews of Board Composition, Leadership Structure, and Financial Performance," Strategic Management Journal, 19, 3, pp. 269-290.

de Andrés, P., V. Azofra, and F. López (2005), "Corporate Boards in OECD Countries: Size, Composition, Functioning and Effectiveness," Corporate Governance: An International Review 13, 2, pp. 197-210.

Donaldson, T. and L.E. Preston (1995), "The Stakeholder Theory of the Corporation: Concepts, Evidence, and Implications," Academy of Management Review, 20, 1, pp. 65-91. 
Dulewicz, V. and P. Herbert (2004), "Does the Composition and Practice of Boards of Directors Bear any Relationship to the Performance of their Companies,? Corporate Governance: An International Review, 12, 3, pp. 263-280.

Eisenhardt, K.M. (1989), "Agency Theory: An Assessment and Review," Academy of Management Review, 14, 1, pp. 57-74.

Erhardt, N.L., J.D. Werbel, and C.B. Shrader (2003), "Board of Director Diversity and Firm Financial Performance," Corporate Governance: An International Review, 11, 2, pp. 102-111.

Evan, W.F. and R.E. Freeman (1993), "A Stakeholder Theory of the Modern Corporation: Kantian Capitalism," in T. Beauchamp and N. Bowie (eds.), "Ethical Theory and Business," Prentice Hall, Englewood Cliffs, NJ, pp. 75-84.

Ezzamel, M. and R. Watson (1993), "Organizational Form, Ownership Structure and Corporate Performance: A Contextual Empirical Analysis of UK Companies," British Journal of Management, 4, 3, pp. 161-176.

Fama, E.F. and M.C. Jensen (1983), "Separation of Ownership and Control," Journal of Law \& Economics, 26, 2, pp. 301-326.

FitzRoy, F.R. and K. Kraft, (1993), "Economic Effects of Codetermination," Scandinavian Journal of Economics, 95, 3, pp. 365-375.

FitzRoy, F. and K. Kraft, (2005), "Co-Determination, Efficiency and Productivity," British Journal of Industrial Relations, 43, 2, pp. 233-247.

Freeman, R.E. (1984), “Strategic Management: A Stakeholder Approach”, Pitman Boston.

Freeman, R.E. and W.M. Evan (1990), "Corporate Governance: A Stakeholder Interpretation," Journal of Behavioral Economics, 194, 337-359.

Freeman, R.E. and Velamuri, S.R.: 2006, ”A New Approach to CSR: Company Stakeholder Responsibility", in A. Kakabadse and M. Morsing (eds.), Corporate Social Responsibility. Reconciling Aspiration with Application, (Houndmills, Palgrave Macmillan), pp. 9-23.

Frye, M.B., E. Nelling, and E. Webb (2006), ”Executive Compensation in Socially Responsible Firms," Corporate Governance: An International Review, 14, 5, pp. 446-455.

Hagen, I.M. and M. Huse (2006) "Do employee representatives make a difference on corporate boards? Examples from Norway," in Proceedings of the European Academy of Management (EURAM) Annual Conference, 2006, Oslo, 17-20 May.

Harrison, J.S. and R.E. Freeman (1999), "Stakeholders, Social Responsibility, and Performance: Empirical Evidence and Theoretical Perspectives," Academy of Management Journal, 42, 5, pp. 479-485.

Hillman, A.J. (2005), "Politicians on the Board of Directors: Do Connections Affect the Bottom Line?," Journal of Management, 31, 3, pp. 464-481.

Hillman, A.J., A.A. Cannella Jr., and R.L. Paetzold (2000), ”The Resource Dependence Role of Corporate Directors: Strategic Adaptation of Board Composition in Response to Environmental Change," Journal of Management Studies, 37, 2, pp. 235-255. 
Hillman, A.J., G.D. Keim, and R.A. Luce (2001), "Board Composition and Stakeholder Performance: Do Stakeholder Directors make a Difference,?” Business \& Society, 40, 3, pp. 295-314.

Hillman, A.J. and Dalziel, T.: 2003, "Boards of Directors and Firm Performance: Integrating Agency and Resource Dependence Perspectives", Academy of Management Review 28, 3, pp. 383-396.

Hollandts, X. (2007), "The moderation effect of board employee representation on employee ownership-firm performance relationship: an empirical examination," in Proceedings of the European Academy of Management (EURAM) Annual Conference 2007, Paris 16-19 May.

Ibrahim, N.A. and J.P. Angelidis (1994), "Effect of Board Members' Gender on Corporate Social Responsiveness Orientation," Journal of Applied Business Research, 10, 1, pp. 35-40.

Ibrahim, N.A. and J.P. Angelidis (1995) "The Corporate Social Responsiveness Orientation of Board Members: Are there Differences between Inside and Outside Directors?, Journal of Business Ethics, 14, 5, 405-410.

Ibrahim, N.I.A., D.P. Howard, and J.P. Angelidis (2003), "Board Members in the Service Industry: An Empirical Examination of the Relationship between Corporate Social Responsibility Orientation and Directorial Type," Journal of Business Ethics, 474, 393-401.

Jensen, M.C. and W.H. Meckling (1976), "Theory of the Firm: Managerial Behavior, Agency Costs and Ownership Structure," Journal of Financial Economics, 3,4, pp. 305-360.

Johnson, R.A. and D.W. Greening (1999), "The Effects of Corporate Governance and Institutional Ownership Types of Corporate Social Performance," Academy of Management Journal, 42, 5, pp. 564-576.

Jones, T. and L.D. Goldberg (1982), "Governing the Large Corporation: More Arguments for Public Directors," Academy of Management Review, 7, 4, pp. 603-611.

Kakabadse, A.P. and N.K. Kakabadse (2007), "CSR in the Boardroom: Myth Or Mindfulness," in A. Kakabadse and N. Kakabadse (eds.), CSR in Practice: Delving Deep, Houndmills, Palgrave Macmillan, pp. 180-205.

Kakabadse, A.P., N.K. Kakabadse and R. Barratt (2006), "CSR in the Boardroom: Contribution of the Non-Executive Director (NED)," in A. Kakabadse and M. Morsing (eds.), "Corporate Social Responsibility: Reconciling Aspiration with Application,” Palgrave Macmillan, Houndmills, pp. 284-299.

Kassinis, G. and N. Vafeas (2002), "Corporate Boards and Outside Stakeholders as Determinants of Environmental Litigation," Strategic Management Journal, 23, 5, pp. 399-414.

Kaufman, A. and E. Englander (2005), "A Team Production Model of Corporate Governance," Academy of Management Executive, 19, 3, pp. 9-22.

Kesner, I.F. (1987), "Directors' Stock Ownership and Organizational Performance: An Investigation of Fortune 500 Companies," Journal of Management, 13, 3, pp. 499-508.

Kochan, T.A. and S.A. Rubinstein (2000), "Toward a Stakeholder Theory of the Firm: The Saturn Partnership," Organization Science, 11, 4, pp. 367-386. 
Letza, S., X. Sun, and J. Kirkbridge (2004), "Shareholding Versus Stakeholding: A Critical Review of Corporate Governance," Corporate Governance: An International Review, 12 ,3, pp. 242-262.

Luoma, P. and J. Goodstein (1999), "Stakeholders and Corporate Boards: Institutional Influences on Board Composition and Structure," Academy of Management Journal, 42, 5, pp. 553-563.

Mahoney, L. and L. Thorn (2006), "An Examination of the Structure of Executive Compensation and Corporate Social Responsibility: A Canadian Investigation," Journal of Business Ethics, 69, 2, pp. 149-162.

McGuire, J., S. Dow, and K. Archgeyd (2003), "CEO Incentives and Corporate Social Performance," Journal of Business Ethics, 45, 4, pp. 341-359.

McKendall, M., Sanchez, C. and Sicilian, P.: 1999, "Corporate Governance and Corporate Illegality: The Effects of Board Structure on Environmental Violations", International Journal of Organizational Analysis 7, 3, pp. 201-223.

Mintzberg, H. (1983), "The Case for Corporate Social Responsibility," Journal of Business Strategy, 4, 2, pp. 3-15.

Mitchell, R.K. and B.R. Agle (1997), "Toward a Theory of Stakeholder Identification and Salience: Defining the Principle of Who and what really Counts," Academy of Management Review, 22, 4, pp. 853-886.

Osterloh, M., B. Frey, and H. Zeitoun (2007), "Voluntary co-determination produces sustainable competitive advantage," in Proceedings of the European Academy of Management (EURAM) Annual Conference 2007, Paris 16-19 May.

Pfeffer, J. (1972), "Size and Composition of Corporate Boards of Directors: The Organization and its Environment," Administrative Science Quarterly, 17, 2, pp. 218-228.

Pfeffer, J. and G.R. Salancik (1978), "The External Control of Organizations: A ResourceDependence Perspective," Harper \& Row, New York.

Post, J.E., L.E. Preston, and S. Sachs (2002), "Managing the Extended Enterprise: The New Stakeholder View," California Management Review, 45, 1, pp. 6-28.

Rajan, R.G. and L. Zingales (1998), "Power in a Theory of the Firm," Quarterly Journal of Economics 113, 2, pp. 387-432.

Ricart, J.E., M.A.Rodríguez, and P. Sánchez, (2005), "Sustainability in the Boardroom: An Empirical Examination of Dow Jones Sustainability World Index Leaders," Corporate Governance: The International Journal of Effective Board Performance, 5, 3, pp. 24-41.

Rodríguez, J.M. (2003), "El gobierno de la empresa: un enfoque alternativo, ediciones Akal, Madrid.

Rodriguez, M.A., J.E. Ricart, and P. Sánchez, (2002), "Sustainable Development and the Sustainability of Competitive Advantage: A Dynamic and Sustainable View of the Firm," Creativity \& Innovation Management, 11, 3, 135-146.

Rosenstein, S. and J.G. Wyatt (1990), "Outside Directors, Board Independence, and Shareholder Wealth," Journal of Financial Economics, 26, 2, 175-191. 
Shrader, C.B., V.B. Blackburn, and P. Iies (1997), "Women in Management and Firm Financial Value: An Exploratory Study," Journal of Managerial, 9, 3, pp. 355-372.

Siciliano, J.I. (1996), "The Relationship of Board Member Diversity to Organizational Performance," Journal of Business Ethics, 15, 12, pp. 1313-1320.

Stanwick, P.A. and S.D. Stanwick (1998), "The Determinants of Corporate Social Performance: An Empirical Examination," American Business Review, 16, 1, pp. 86-93.

Szwajkowski, E. (2000), "Simplifying the Principles of Stakeholder Management: The Three most Important Principles," Business \& Society, 394, 379-396.

Tirole, J. (2001), ”Corporate Governance,” Econometrica, 69, 1, pp. 1-35.

van der Walt, N. and C. Ingley (2003), "Board Dynamics and the Influence of Professional Background, Gender and Ethnic Diversity of Directors," Corporate Governance: An International Review, 11, 3, 218-234.

Vinten, G. (2001), "Shareholder Versus Stakeholder - is there a Governance Dilemma?," Corporate Governance: An International Review, 9, 1, 36-47.

Wang, J. and B.S. Coffey (1992), "Board Composition and Corporate Philanthropy," Journal of Business Ethics, 11, 10, 771-778.

Wang, J. and H.D. Dewhirst (1992), "Boards of Directors and Stakeholder Orientation," Journal of Business Ethics, 11, 2, 115-123.

Webb, E. (2004), "An Examination of Socially Responsible Firms' Board Structure," Journal of Management and Governance, 8, 3, pp. 255-277.

Westphal, J. (1999), "Collaboration in the Boardroom: Behavioral and Performance Consequences of CE0-Board Social Ties, Academy of Management Journal, 42, 1, pp. 7-24.

Williams, R.J. (2003), "Women on Corporate Boards of Directors and their Influence on Corporate Philanthropy," Journal of Business Ethics, 42, 1, pp. 1-10.

Williamson, O.E. (1984), ”Corporate Governance," Yale Law Journal, 93, pp. 1197-1230.

Zahra, S.A., B.M. Oviatt, and K. Minyard (1993), "Effects of Corporate Ownership and Board Structure on Corporate Social Responsibility and Financial Performance," Academy of Management Proceedings, pp. 336-340.

Zahra, S.A. and Stanton, W.W.: 1988, "The Implications of Board of Directors' Composition for Corporate Strategy and Value", International Journal of Management 5, 229-236.

Zingales, L. (1998), "Corporate Governance”, in P. Newman (ed.), "The New Palgrave Dictionary of Economics and the Law," Macmillan, London, pp. 497-503. 